\title{
WAYS OF RADICAL CHANGE OF THE IMAGE OF TAX AND CUSTOMS OFFICERS
}

\author{
Anna Harutyunyan, \\ Lecturer of the Armenian State University of Economics, candidate of economics \\ Tigran Harutyunyan, \\ Economist, docent, Yerevan State University lecturer
}

DOI: https://doi.org/10.31435/rsglobal_ijite/30042019/6449

\begin{abstract}
ARTICLE INFO
Received 17 February 2019

Accepted 15 April 2019

Published 30 April 2019

\section{KEYWORDS}

tax system, tax administration,
\end{abstract} customs code, international standards, advanced technology, legislative reform, internal Revenue.

Citation: Anna Harutyunyan, Tigran Harutyunyan. (2019) Ways of Radical Change of the Image of Tax and Customs Officers. International Journal of Innovative Technologies in Economy. 3(23). doi: 10.31435/rsglobal_ijite/30042019/6449

Copyright: (C) 2019 Anna Harutyunyan, Tigran Harutyunyan. This is an open-access article distributed under the terms of the Creative Commons Attribution License (CC BY). The use, distribution or reproduction in other forums is permitted, provided the original author(s) or licensor are credited and that the original publication in this journal is cited, in accordance with accepted academic practice. No use, distribution or reproduction is permitted which does not comply with these terms.

Noticeable improvements have been made in tax system in recent years. Great work has been undertaken to improve the quality of service of taxpayers and to increase the services rendered. Significant achievements have been recorded especially with respect to introduction of modern high technologies in customs procedures, training of qualified staff, as well as improvement of the RA customs code and compliance with international standards. [7]

Human resources policy has its unique role in the development of tax sector, improvement of administrative instruments and increase of efficiency of the system. Along with implementation of legislative reforms and application of advanced technologies for increase of confidence in tax system and expansion of capabilities, the role of a professional tax officer is of high importance. In terms of efficiency of tax administration if the organizational structure is considered to be the skeleton of the system, human resources are the driving force of this skeleton. Therefore, development of knowledge of the officers is a top priority objective of tax and customs system, for the achievement of which human resources management policy and comprehensive strategy shall be established that will comprise the key component of the primary strategy of the tax authorities activities. Here the question arises as to whether tax authorities provide various ongoing training courses in line with international standards, instructional training materials, opportunities to exchange experience with foreign countries and whether the system has qualified lecturers with necessary experience, etc.

The radical change of the image of tax and customs officers is viewed from two aspects:

1. Development of professional skills and knowledge;

2. Maintenance of code of conduct.

The main form of development of professional knowledge is training. Training of staff it is not just a one-time training, but also a planned continuing professional training, through upgrading of knowledge 
and awareness, development of skills, which is the main condition for achievement of the objectives set for tax officers. In many cases training courses in public sector are set by the budget and regulated by relevant laws (laws on internal audit, tax and customs services). Around the world, leading organizations of both public and private sectors make huge investments in professional development of their staff. Professional activities of tax and customs officers assume availability of knowledge and skills for a number of professions, including accounting, tax system, law and modern information technologies. [1]

Aiming to ensure the high efficiency of achievement of general objectives, in addition to knowledge, communication skills and ability to integrate into teamwork are required. Time challenges constantly change the objectives set for tax system, which in their turn change the requirements specified for professional skills of the officers, therefore, trainings should be of continuing nature. Human resources policy of tax and customs system is targeted at the following three areas: training of new professionals, continuing training of experienced officers and provision of opportunities for career growth. In order to improve the behavior of tax and customs officers training needs per sectors and positions should be thoroughly analyzed and long-term priorities should be set. Consequently, training of tax and customs should be organized both through educational institutions and professional training institutions operating adjunct to the state authorities, ensuring close relationship between the institutions generating supply and dictating demand. Considering the above the State Revenue Committee (SRC) of Armenia cooperates with higher educational institutions. For this purpose, master's educational program with specialization in tax and customs spheres is implemented in the State Economic University of Armenia.

Equal training opportunities, career growth in line with relevant knowledge and experience cause the officers to strive for deepening their knowledge and developing skills. Since Armenia is a member of several international associations and is a party to various agreements, tax and customs officers should complete appropriate trainings corresponding to international standards, receive sufficient information and technical support, training strategy should be developed for them and other mechanisms of professional development should be applied and they should have an opportunity to participate in international training programs. In international practice there exist various forms and methods of trainings, such as collective, group, individual, classroom and distance trainings, trainings by electronic media, by educational and didactic materials, online courses, etc. Each inexperienced employee with various professions (accounting, audit, tax system, law, information technologies) must overcome the barrier of integration into the team and teamwork, possession the required skills and gaining the experience, the duration and results of which are individual for each of them. The Internal Revenue Service of America, for effective integration of new employees, organizes induction training course at the workplace and includes in working teams both experienced and less experienced employees.

Tax and customs system is a multifunctional structure, therefore, in order to ensure unified application of the legislation, professional training of staff should be organized by means of guidelines, workshop discussions, qualification trainings and other instruments, which should be attended by the employees of territorial and regional tax and customs authorities. The organizational structure of tax and customs system has been established based on functional principle, however it comprises also subdivisions for types of taxes, and for proper performance of these functions responsible employees are required to possess relevant knowledge about the functions, appropriate skills and complete trainings. Training programs need to distinguished:

- based on functions, specialized and general topics;

- based on management level (managerial staff, lower and medium level managers).

Trainings on general topics should be mandatory for all tax and customs officers, and should include the categories listed below:

- economic;

- civil;

- legal;

- moral and psychological, code of conduct;

- social and political, etc. [1]

For example, the internal auditors are required to possess proficient knowledge on internal audit, legislation related to tax and public finance management and internal control system, to have qualification of internal auditor and to complete annual mandatory trainings on specialized and other general topics. 
Individual training programs should be defined for each level of management, where clear emphasis should be made on management issues, particularly on setting, review and timely performance of the task, monitoring, accountability and development of the employees' knowledge. Training of managerial staff is also important due to the fact that managers establish necessary procedures for performance supervision, especially when it refers to their own staff. In addition to the responsibility for proper performance of activities and accountability at different levels, they are involved in the certification process, they assess the performance results of officers and determine the need for training courses and their directors. In general, along with specialized trainings the managerial staff should attend various training courses on development of leadership skills.

The main steps of efficient training are:

1. Assessment of training needs;

2. Preparation of training plan, programs;

3. Development and organization of training;

4. Assessment of training efficiency.

Training results include:

1. Development of knowledge of the officers;

2. Motivation of the officers;

3. Proper use of capabilities of the officers. [6, c 350]

System of regular training of tax officers has been introduced in tax system of Armenia. In the SRC tax and customs officers training function is performed by the educational center operating under subordination of the committee. The mission of the center is the training of tax and customs officers, taxpayers, development of professional knowledge and technical skills, cooperation with international bodies, preparation and provision of information and analytical materials.

Training courses organized for tax and customs officers in the center are of more specialized nature and cover the most important issues of tax and customs legislation, particularly, customs legislation and administration, introduction of external audit tools in customs audit, electronic management system, tax legislation, tax inspections and supervision. Topics of trainings are proposed by tax and customs services based on current requirements.

Trainings on various topics are set based on functions. These are:

1. Tax service

- training of the officers performing legal function;

- training of the officers performing taxpayers service function;

- training of the officers performing current supervision and inspections function;

- training of the officers performing operative investigation function.

2. Customs service

- training of the officers of collection coordination and accounting departments;

- training of the officers of customs tariffs and customs registration departments; smuggling. [8]

- training of the officers performing functions of pre-clearance control and fight against

Upon completion of trainings computer-based test shall be passed. The employees with positive results ( 80 points and higher) have an opportunity to pass paper-based certification.

For comprehensive solution of practical issues arising during implementation of tax system reforms and in order to have human resources who satisfy international standards, around 1000 tax and customs officers should be trained by annual working and educational plan. Aiming to raise awareness of taxpayers and to increase tax revenue training courses for taxpayers are also organized in the center. [8]

The rapid development of internet and web technologies enables a faster exchange of information, as well as cooperation and interaction among the users. In recent years, up-to-date becomes the distance learning via internet. In 2015, distance learning pilot system was introduced in the training center and educational processes are organized online, without taking off the employees from their work and workplace. Distance learning, being flexible, mass scale and effective, enables to organize workshops, discussions and trainings on challenging issues in short period of time.

In 2012-2013 around 8000 tax and customs officers were trained in the center and in 2016, 90 groups included 1974 participants. 
Table 1. Information on training of employees of tax and customs authorities [3]

\begin{tabular}{|c|c|c|c|}
\hline Indicators & 2014 & 2015 & 2016 \\
\hline \multicolumn{4}{|l|}{ Tax authorities } \\
\hline Number of tax officers & 1913 & 1877 & 1674 \\
\hline Number of trained tax officers & 1455 & 1539 & 1428 \\
\hline Number of certified officers & 141 & 503 & 92 \\
\hline $\begin{array}{l}\text { Number of officers who received grade or special } \\
\text { degree }\end{array}$ & 290 & 278 & 168 \\
\hline Number of recruitments conducted & 4 & 5 & 1 \\
\hline Number of employees hired as a result of recruitment & 80 & 166 & 25 \\
\hline \multicolumn{4}{|l|}{ Customs authorities } \\
\hline Number of customs officers & 791 & 814 & 739 \\
\hline Number of trained customs officers & 550 & 583 & 544 \\
\hline Number of certified officers & 12 & - & - \\
\hline Number of officers who received special degree & 86 & 144 & 45 \\
\hline Number of recruitments conducted & 5 & 1 & 1 \\
\hline Number of employees hired as a result of recruitment & 18 & 1 & 64 \\
\hline
\end{tabular}

In $2016,85 \%$ of tax officers and $74 \%$ of customs officers were trained.

Staff training is also conducted in international training centers of international organizations, which contributes to modernization of tax and customs system.

In the system unified procedures are developed in the head office and afterwards are assigned to tax inspectorates. Therefore, for implementation of modern control mechanism over their performance and for ensuring unified business behavior, in addition to trainings, discussions on behavior, instruments and legislative changes are organized in the form of workshop discussions.

One of the pillars of the functional organizational structure of tax system is the staff performance assessment system, which should be based not only on the taxes collected, but also on the efficiency and other functional indicators, resulting in employees seeking to achieve higher results. Based on the performance assessment results needs for training and its directions are determined.

Trainings of tax and customs officers are regulated by relevant legislative acts, based on which training educational programs, certification performance and evaluation procedures are set.

The certification of tax officers is carried out once every 3 years. Those tax officers who get 80 or higher points based on total training results within the period following the previous certification and positive efficiency report are subject to paper-based certification. Paper-based certification is performed based on the efficiency report, by an interview. [4] The efficiency report is provided by the immediate supervisor, taking into account the efficiency of the employee's performance. Training of tax and customs officers represents additional professional training with duration of 80 academic hours (from 2016) organized by tax and customs authorities. After training participants' advancement assessment is performed by 100 -point scale, as follows:

- score of 95 (inclusive) and higher is assessed as excellent advancement;

- score 90-95 is assessed as good advancement;

- score 80-90 is assessed as satisfactory advancement;

- score of lower than 80 is assessed as satisfactory advancement. [5]

Each year at least one-third of tax officers is subject to mandatory training, which is arranged for the improvement of specific requirements set for the rights and obligations specified by the job description for the given position of the service and for possession of professional knowledge and operational skills. The officers' training costs are covered by the funds of the service and the state budget. In addition to mandatory training prescribed by the law, the officers can attend various courses for personal development, which may or may not be aimed at improving the quality of performance of professional duties.

Along with the measures of the State Revenue Committee targeted at the effective staff management, the maintenance of code of conduct by the officers is also in focus. Rules that guide conduct of an officer of European tax system assume:

- professionalism; 
- objectivity;

- honesty;

- integrity;

- fairness;

- independence, etc. [2]

According to European standards, tax authorities are obliged to ensure the above listed requirements of internal and external behavior of its employees. The SRC, wishing to ensure and develop communication and interaction skills of its staff resulting from professional behavior, has established a code of conduct for tax and customs officers, the maintenance of which is mandatory both on and off duty.

The code of conduct of tax and customs officers represents norms based on generally accepted principles of morality, which regulate behavior, conduct and relationship peculiarities of a tax officer in accordance with the tax and customs service procedures.

The code of conduct has been established for the purpose of guiding the behavior of tax officers.

Tax and customs officer is obliged to:

- demonstrate unconditional loyalty and commitment to his/her country and work; discredit it;

- refrain from actions that may hinder the activities of the state body or undermine and

- be guided by moral norms based on principles of humanity, fairness and honesty;

- respect human dignity;

- be impartial, objective, independent, discreet and lead by example;

- avoid undue emphasizing of his/her position;

- be balanced, disciplined and truthful;

- be polite with taxpayers, partners, subordinates and management;

- avoid any kind of protectionism, mediation, assistance as a result of which compliance with requirements of tax laws can be obstructed, to use only moral actions for achievement of goals during the service;

- not to fall into a position of dependence due to his/her behavior and be independent;

- maintain unconditionally the confidentiality of official information aiming to ensure the secure operation of customs service. $[9,10]$

The immediate supervisor of the tax officer, following the rules of professional conduct, undertakes measures to the extent possible to ensure observance of these rules by his/her subordinates. In case of their violations or improper maintenance, relevant penal measures will be applied. In 2015 2016 for inappropriate performance of duties and improper maintenance of code of conduct, tax and customs were subjected to disciplinary action.

Table 2. Number of officers subjected to disciplinary action of the SRC [3]

\begin{tabular}{|l|c|c|}
\hline \multicolumn{1}{|c|}{ Indicators } & 2015 & 2016 \\
\hline Customs officers & & 3 \\
\hline Warning & 5 & - \\
\hline Strong warning & 4 & 40 \\
\hline Tax officers & 74 & 17 \\
\hline Verbal warning & 49 & - \\
\hline Written warning & 1 & \\
\hline Downgrading & & \\
\hline
\end{tabular}

Effective tax administration requires not only highly qualified, but also polite tax and customs officers, who will strictly maintain the rules of professional conduct and ensure proper compliance with moral and psychological norms during their service.

The above stated studies and researches allow drawing certain conclusions and providing recommendations as presented below:

1. Thus, the solution of issues faced by the economy attaches importance to radical change of the image of tax and customs officers and enhancement of professional qualification, which can be achieved through quality education and continuing professional development. Development of staff knowledge and analytical capabilities will bring new quality and approach in human resources policy and training processes of the SRC. Only high professional quality of staff can ensure a high level 
customer service, which in its turn will serve as a precondition for improving tax culture in Armenia. Within the scope of tax and customs reforms human resources management strategy and policy are set, which will contribute to the achievement of goals of tax authorities and development of staff members through clearly designed trainings and professional development.

2. The main ways of radical change of the image of tax and customs officers are as follows:

2.1. Management of tax system personnel should include complex measures of staff recruitment, proper allocation, training and motivation, and should be also targeted at training of candidates pool, which should guarantee the availability of human resources for the system.

2.2. The key condition for ensuring high performance indicators and development of professional knowledge is the existence of incentives (motivation) system. Incentives system must be consistent with the achievement of the objectives of tax system. The right combination of payment and incentives systems will contribute to the social security of the officer, which will allow him/her to be independent when performing professional duties. Tax and customs officers comprising a part of the society, by their lifestyle and behavior help on formation of the opinion on the system.

2.3. Mandatory trainings prescribed by the law are financed by the state budget, therefore, the effective and purposeful management of public finance requires the training costs to be targeted by contributing to the increase of efficiency of tax administration. Consequently, two approaches for the assessment of training efficiency (cost-outcome) should be applied: efficiency analysis of the organization that conducts training and assessment of qualitative and quantitative changes in the performance of duties by the officers after training.

2.4. The key factor of efficiency of tax administration is the availability of professional, courteous and knowledgeable staff. For this purpose, tax and customs officers gain new qualitative skills through trainings (local and international) corresponding to international standards. To avoid wasted efforts and resources, the system should undertake measures for the reduction of staff outflow. Thus, figures presented in human resources management section of 2016 report of tax and customs system show that human resources outflow from the system is quite high, that is 203 employees, which is to some extent conditional upon optimization of the structure of tax inspectorates that implies reduction of number of tax inspectorates and establishment of service centers. Instead of hiring new employees for the system, it is reasonable to arrange rotation of the experienced staff through trainings.

\section{REFERENCES}

1. Сулейманов Д.Н, Основные направления совершенствования профессиональной подготовки и повышения квалификации работников налоговых органов, http://www.rosnou.ru/nalog-i_ru/news_141014/

2. Assessment program of administrative capabilities of the State Tax Service adjunct to the RA government, Booz Allen Hamilton Inc., 2007, p. 452

3. Annual report on the activities of tax and customs authorities, 2016, p. 92

4. Law on Tax Service, 03.07.2002

5. State Revenue Committee, 15.11.2013, order N 508-N

6. Detailed Guidelines for Improved Tax Administration in Latin America and the Caribbean, USAID, 2013, p 530

7. http://henaran.am/51088.html\#sthash.QAXvxib5.dpuf

8. www.mftc.am

9. www.taxservice.am

10. www.customs.am 